\title{
DYNAMIC CAPABILITIES DALAM DEMOKRATISASI PELAYANAN PUBLIK DI INDONESIA PADA MASA PANDEMI COVID-19
}

\author{
${ }^{1}$ Resa Vio Vani \\ 'Universitas Riau \\ Resavani31@gmail.com \\ Pekanbaru, Riau, Indonesia
}

\begin{abstract}
required to be able to provide public services in limited interactions. Therefore, the dynamic governance ability shown in this study aims to reveal public expectations in public services during Covid-19 through policy, and to understand the realization of objectives that must be fully understood. As well as how the democratization of public services should be the road to service excellent seen based on the theory of dynamic capabilities that are part of dynamic governance, where able people and agile processes become the benchmark of good implementation of public services, using 3 indicators namely Thinking Ahead, Thinking Again, and Thinking Across. all this is a process towards democratizing public services in Indonesia. This research is a qualitative method with a library study approach. The results stated that Indonesia needs to transform public services using the concept of dynamic capabilities in order to realize the democratization of public services.
\end{abstract}

Keywords: Coronavirus Disease 2019; Democratization; Dynamic Capability; Public Service

\begin{abstract}
Abstrak
Coronavirus disease 2019 merupakan bencana besar bagi birokrasi apatis, sehingga pemerintah dituntut agar mampu memberikan pelayanan publik dalam keterbatasan interaksi. Maka dari itu kemampuan tata kelola dinamis yang ditunjukkan dalam penelitian ini bertujuan untuk mengungkap ekspektasi masyarakat dalam pelayanan publik dimasa Covid-19 melalui kebijakan, dan untuk memahami realisasi tujuan yang harus dipahami sepenuhnya. Serta bagaimana demokratisasi pelayanan public harus menjadi the road to service excellent yang dilihat berdasarkan teori dynamic capabilities yang merupakan bagian dari dynamic governance, dimana able people dan agile proses menjadi tolak ukur implementasi pelayanan publik yang baik, dengan menggunakan 3 indikator yaitu Thinking Ahead, Thinking Again, dan Thinking Across. semua ini merupakan proses menuju demokratisasi pelayanan publik di Indonesia. Penelitian ini metode kualitatif dengan pendekatan studi pustaka. Hasil penelitian menyebutkan bahwa Indonesia membutuhkan transformasi pelayanan public menggunakan konsep dynamic capabilities demi mewujudkan demokratisasi pelayanan publik.
\end{abstract}

Kata Kunci: Coronavirus Disease 2019; Demokratisasi; Kapabilitas Dinamis, Pelayanan Publik

Open Access at:http://ojs.uho.ac.id/index.php/PUBLICUHO/index

Journal Publicuho is licensed under a Creative Commons Attribution 4.0 International License. 


\section{Journal Publicuho}

ISSN2621-1351 (online), ISSN 2685-0729 (print)

Volume 4 Number 1 (February-April), (2021)pp.158-170

Accredited SINTA SK.NOMOR 28/E/KPT/2019

Open Access at:http://ojs.uho.ac.id/index.php/PUBLICUHO/index

DOI: 10.35817/jpu.v4i1.16458

\section{PENDAHULUAN}

Covid19 (Coronavirus disease 2019) pertama kali muncul di Wuhan, China, kemudian menyebar ke seluruh belahan dunia. Saat Covid-19 mulai muncul pada akhir tahun 2019 dan mulai menyebar secara lokal di China pada akhir Januari 2020, lalu menyebar secara global sepanjang Februari hingga akhir Mei. Pada 28 Mei 2020, pemerintah pusat akan menjadi penanggung jawab Departemen Perencanaan Pembangunan Nasional / Bappenas pada jumpa pers yang diadakan pada 28 Mei 2020 dengan Menteri Luar Negeri Retno Marsudi dan Kelompok Ahli Satgas Covid-19. Orang-orang, mendorong "Covid-19 Productivity and Safe Society Protocol" ke kondisi normal baru (New Normal).

Pandemi Covid-19 telah banyak mengajarkan kita dalam hal tata kelola birokrasi. Dalam kondisi bagaimanapun, birokrasi harus tetap menjadi garda depan untuk memberikan pelayanan publik. Era Covid-19 ini membuat birokrasi harus mengoptimalkan pemanfaatan teknologi, informasi dan komunikasi dalam segala hal di sektor pemerintahan. Akibat terbatasnya ruang gerak karena mengikuti protokol kesehatan, masyarakat tetap diberikan haknya sebagai warga negara untuk dilayani melalui layanan elektronik. Transformasi model pelayanan manual yang ditandai dengan pelayanan tatap muka ke elektronik terus mengalami pelonjakan yang signifikan di masa Covid-19. Pergeseran paradigma dalam mengelola organisasi di era unpredictable serta kompleks membuat organisasi untuk perlu melakukan penyesuaian melalui sebuah proses perubahan. Perubahan organisasi adalah usaha untuk mempertahankan kelangsungan hidup agar tetap survive menghadapi permasalahan yang tidak pasti seperti Covid-19. Organisasiorganisasi yang cepat beradaptasi dengan perubahan lingkungan adalah organisasi yang survive. Tantangan-tantangan sosial yang muncul pasca merebaknya pandemic COVID-19 memaksa lembaga-lembaga publik atau institusi pemerintah untuk melakukan akselerasi digital untuk mengoptimalisasi layanan public.

Pelayanan publik di negara demokratis berarti penghormatan terhadap hak Individu dan kelompok menghormati hukum dan peraturan keadilan, Dan akses yang adil ke layanan berkualitas di semua industri, Semua warga negara bebas dari diskriminasi dalam hidup. layanan Ketika nilai-nilai etika dipertahankan dengan cara-cara berikut, maka akan tercipta masyarakat yang berkualitas Integritas untuk memberikan layanan berkualitas kepada warga negara Semua ras, agama, ras dan kepercayaan, Kepuasan dan keadilan. Kapabilitas dinamis ini harus dibangun dari dalam organisasi melalui pengalaman yang terkumpul dan tidak dapat dibeli atau diperoleh dari luar organisasi. Dengan menetapkan dan menerapkan konsep kapabilitas dinamis, organisasi sektor publik pada akhirnya dapat menciptakan kapabilitas yang dapat merumuskan kebijakan adaptif dan merespons perubahan lingkungan yang cepat. 


\section{Kapabilitas Dinamis}

Kapabilitas dinamis menurut Aminullah (2015) tidak akan terjadi secara alami. Ini adalah hasil dari keinginan dan ambisi pimpinan untuk menjamin kelangsungan hidup masyarakat. Pemimpin yang energik akan berpikir dengan cara yang berbeda, mengekspresikan ide-ide mereka, sehingga rekan kerja dan atasan menghargai dan mendukung mereka, dan mengubah alokasi sumber daya ke organisasi untuk mencapai fungsi yang diperlukan dalam waktu yang berkelanjutan. Kompetensi mengacu pada sikap, pengetahuan, keterampilan, dan sumber daya organisasi yang digunakan untuk membayangkan dan melakukan tugas terkoordinasi untuk mencapai hasil yang diinginkan.

Piening (2013) Beberapa percaya bahwa jika kapabilitas dinamis tidak terus-menerus diperbarui, organisasi sektor publik akan mengalami kesulitan untuk merespons perubahan lingkungan mereka secara efektif. Oleh karena itu, perlu dikaji secara mendalam bagaimana membangun kapabilitas dinamis organisasi sektor publik dari berbagai perspektif peneliti. Menurut Kazim dalam Tahir (2017) Kemampuan sebagian mencerminkan cara berpikir orang Singapura berdasarkan tiga hal: berpikir ke depan, berpikir ulang, dan berpikir. Berpikir ke depan menunjukkan kemampuan berpikir dalam merumuskan kondisi masa depan yang dapat mempengaruhi kondisi domestik. Sebaliknya, pemikiran ulang akan mencerminkan kemampuan dan keterbukaan untuk merefleksikan kebijakan sebelumnya, kemudian mengevaluasi dan menyempurnakannya untuk memaksimalkan tujuan. Sedangkan berpikir adalah kemampuan dan keterbukaan wawasan dalam pengalaman mempelajari pemikiran dan konsep peserta lain.

Zollo dan Winter dalam (Darusman, 2020) menyatakan Kemampuan dinamis adalah mode pembelajaran dan stabil dari serangkaian aktivitas yang dilakukan oleh organisasi untuk melakukan produksi secara sistematis dan mengubah aktivitas operasi hariannya untuk mencapai hasil yang lebih baik. Pablo et al pada Darusman (2020) Sektor publik diyakini lebih banyak menghadapi perubahan lingkungan daripada sektor komersial, misalnya adanya perubahan kebijakan tertentu yang membuat proses bisnis organisasi harus segera beradaptasi. Oleh karena itu, upaya membangun kapabilitas dinamis dipandang sebagai faktor utama dalam keberhasilan organisasi sektor publik.

Tata kelola yang dinamis mencapai relevansi dan efektivitas saat ini dan masa depan melalui strategi yang terus beradaptasi dengan lingkungan yang berubah. Peraturan dan struktur pemerintahan adalah pilihan yang dibuat oleh masyarakat dan mencerminkan nilai-nilai dan kepercayaan para pemimpinnya, yaitu menempatkan kepercayaan pada tujuan dan harapan tertinggi yang diperoleh pemerintah dari rakyat. Norma informal dan mekanisme implementasi yang dilembagakan menjadi satu kebijakan. 


\section{Journal Publicuho}

ISSN2621-1351 (online), ISSN 2685-0729 (print)

Volume 4 Number 1 (February-April), (2021)pp.158-170

Accredited SINTA SK.NOMOR 28/E/KPT/2019

Open Access at:http://ojs.uho.ac.id/index.php/PUBLICUHO/index

DOI: 10.35817/jpu.v4i1.16458

\section{Demokratisasi Pelayanan Publik}

Demokratisasi dalam proses perumusan kebijakan publik spesialnya dalam perihal perpajakan kali ini bisa dimengerti bagaikan akomodasi kepentingan warga dalam kebijakan dan terdapatnya partisipasi warga dalam proses pembuatan kebijakan. Pengusungan nilai- nilai demokrasi seperti halnya keadilan serta pemerataan kerap kali berbenturan dengan nilai- nilai birokrasi yakni nilai daya guna serta pertanggungjawaban. Sebab akan timbul dampak domino seperti aksi dari pelayanan yang transparan dan senantiasa menimbulkan bentuk partisipatif, responsif serta akuntabel. Aksi pemerintah yang partisipatif memicu munculnya transparansi, responsivitas serta akuntabilitas. Aksi yang responsive menuntut transparansi, akuntabilitas serta pastisipasi aktif dari masyarakat. Terhubung dengan akuntabilitas yang menuntut transparansi, partisipatif, dan responsif.

Demokratisasi merupakan bagian dari perpolitikan yang lebih demokratis baik dalam hal pemerintahan maupun yang berhubungan dengan kepentingan publik. Substansial demokratisasi merupakan kewajiban Negara untuk melakukan optimalisasi dalam memberikan perlindungan kepada masyarakat, terutama ada hal hak- hak masyarakat, terutama pada pelaksanaan regulasi kelayakan menjalankan kehidupan dalam berbagai aspek. Oleh karena itu pemerintah harus mengatur serta mengelola indikasi hierarki yang muncul dan wajib mengorganisasi serta mengintegrasikan aktivitas manusia demi mewujudkan visi misi pemerintahan. Dan dalam skala universal untuk demokratis kebijakan dalam hal mencapai kesejahteraan warganya.

Bagi Heru (2012) Hak yang dimiliki masyarakat wajib diperjuangkan serta disalurkan pada sistem politik demokratis yakni merupakan: (1) Keinginan untuk memperoleh otoritas agar birokrat terpilih memutuskan sebuah kebijakan,(2) Kemampuan agar mendapatkan ekspansi atas hak memilih, (3) Kemampuan untuk menciptakan subyek yang berhubungan dengan harapan pemilih, (4) perjuangan perhitungan yang jujur, (5) Perjuangan untuk diterimanya bagaikan aktor sosial dengan legitimasi bagaikan partisipan, (6) Kemampuan untuk menciptakan partisipasi dari warga yang secara individu bergantung kepada dominansi kelompok.

Bagi Partini( 2012) Demokratisasi dikira bagaikan sesuatu sistem politik terbarukan yang sangat sesuai buat mewadahi aspirasi serta kepentingan tidak cuma dari golongan elit politik saja, tetapi warga universal secara totalitas. Demokratisasi dipengaruhi oleh bermacam aspek semacam pembangunan ekonomi, sejarah, serta warga madani. Demokratisasi pula berarti transparansi kebijakan, maksudnya tiap kebijakan yang diambil wajib jelas siapa yang memprakarsai atau menginisiasi, apa tujuannya serta berapa anggaran yang wajib dikeluarkan, dan siapa yang wajib bertanggungjawab bila kebijakan itu kandas.( Haris, S. 2005) 
Pelayanan adalah setiap kegiatan yang menguntungkan dalam suatu kumpulan atau kesatuan, dan menawarkan kepuasan meskipun hasilnya tidak terkait pada suatu produk secara fisik. (Kotler dalam Sinambela, 2006 : 4). Berdasarkan pendapat tersebut, dapat dikatakan bahwa pada dasarnya 10 pelayanan merupakan sesuatu yang tidak berwujud tetapi dapat dirasakan sehingga bisa memenuhi kebutuhan dan memberi kepuasan kepada masyatrakat. Kewajiban pemerintah adalah memberikan pelayanan publik yang menjadi hak setiap warga negaranya ataupun memberikan pelayanan kepada warga 13 Negara yang memenuhi kewajibannya terhadap Negara. Bentuk pelayanan publik yang diberikan kepada masyarakat dapat dibedakan ke dalam beberapa jenis pelayanan, yaitu: a. Pelayanan pemerintah, adalah jenis pelayanan masyarakat yang terkait tugas-tugas umum pemerintah seperti pelayanan KTP, SIM, pajak, dan keimigrasian b. Pelayanan pembangunan, yaitu suatu jenis pelayanan masyarakat yang terkait dengan penyediaan sarana dan prasarana untuk memberikan fasilitasi kepada masyarakat dalam melakukan aktifitasnya sebagai warga Negara c. Pelayanan utilitas, yaitu jenis pelayanan yang terkait utilitas bagi masyarakat. d. Pelayanan sandang, pangan, dan papan, merupakan jenis pelayanan yang menyediakan bahan kebutuhan pokok masyarakat dan kebutuhan perumahan e. Pelayanan kemasyarakatan, yaitu jenis pelayanan masyarakat yang dilihat dari sifat dan kepentingannya lebih ditekankan pada kegiatan-kegiatan social kemasyarakatan (Badu Ahmad, 2013 : 30-31).

Nilai demokrasi dapat dirasakan dan dinikmati oleh masyarakat melalui pelayanan public yang baik, dengan adanya transparansi, partisipatoris, responsive dan akuntabilitas. Maka dari itu demokratisasi dalam pelayanan publik menjadi pondasi dalam sebuah Negara. Bagaimana Negara mampu memberikan pelayanan tanpa mendiskriminasi yang menimbulkan misunderstanding atau terbenturnya public trust yang dapat menciptakan image negative bagi Negara itu sendiri. Demokratisasi pelayanan public harus menjadi jalan menuju Negara yang demokrasi, dengan memperhatikan kualitas pelayanan yang dipengaruhi oleh kebutuhan dan ekspektasi sehingga tujuan dari sebuah Negara dapat tercapai, yakni kesejahteraan yang merata dan kebrlanjutan.

\section{Coronavirus Disease 2019}

COVID-19 adalah penyakit menular yang disebabkan oleh virus korona yang baru ditemukan. Ini adalah virus baru, penyakit yang tidak diketahui sebelum wabah di Wuhan, China pada Desember 2019. Gejala COVID-19 yang paling umum adalah demam, rasa lelah, dan batuk kering. Beberapa pasien mungkin mengalami nyeri, hidung tersumbat, pilek, sakit tenggorokan atau diare. Gejala biasanya ringan dan muncul secara bertahap. Beberapa orang yang terinfeksi tidak menunjukkan gejala tetapi tetap merasa baik.

Menurut Rothan \& Byrareddy (2020) Orang bisa tertular COVID-19 dari orang lain yang tertular virus. Saat pasien batuk atau mengeluarkan napas, COVID-19 dapat menyebar dari 


\section{Journal Publicuho}

ISSN2621-1351 (online), ISSN 2685-0729 (print)

Volume 4 Number 1 (February-April), (2021)pp.158-170

Accredited SINTA SK.NOMOR 28/E/KPT/2019

Open Access at:http://ojs.uho.ac.id/index.php/PUBLICUHO/index

DOI: 10.35817/jpu.v4i1.16458

orang ke orang melalui tetesan di hidung atau mulut. Percikan api ini kemudian jatuh pada objek dan permukaan sekitarnya. Orang yang menyentuh benda atau permukaan ini dan kemudian mata, hidung, atau mulutnya mungkin terinfeksi COVID-19. United Nations Conference on Trade and Development (UNCTAD, 2020) dalam Muhyiddin (2020) la mengatakan Covid-19 telah melanda negara-negara berkembang.Setelah merebaknya pandemi Covid-19, beberapa hal berdampak pada perekonomian. Artinya, krisis utang yang sedang berlangsung tidak terbatas pada negara berkembang termiskin, tetapi juga mempengaruhi semua kategori pendapatan.

\section{METODOLOGI}

Metode penelitian yang digunakan dalam tulisan ini adalah metode deskriptif kualitatif, dengan jenis penelitian kepustakaan (library research). Penelitian pustaka merupakan serangkaian kegiatan yang berkenaan dengan metode pengumpulan data pustaka, membaca, dan mencatat serta mengolah bahan penelitian (Zed, 2004). Desain penelitian dilakukan melalui beberapa tahapan, yaitu sebagai berikut: pertama, menelusuri, mencatat, dan membaca berbagai temuan terkait pembahasan birokrasi maupun kebijakan di era Covid-19 secara umum pada setiap pembahasan hasil penelitian, artikel, maupun berita yang didapatkan dalam literatur-literatur, dan sumber website lembaga resmi pemerintah, maupun lembaga internasional, serta sumber-sumber lainnya yang relevan dengan studi ini. Kedua, memadukan segala temuan, baik teori, model maupun konsep perubahan organisasi dan transformasi pelayanan publik. Ketiga, menganalisis setiap temuan dari berbagai bacaan, baik dari sisi kelebihan, kekurangan, maupun keterkaitan tentang tulisan yang dibahas. Tahapan terakhir adalah memberikan ulasan kritis dengan mengelaborasi model maupun pendekatan yang berbeda dari temuan dalam artikel sebelumnya.

\section{HASIL DAN PEMBAHASAN}

Tata kelola dinamis adalah bentuk pengembangan lain untuk memahami ilmu pemerintahan dan metode manajemen publik modern. Ini membantu untuk memahami masalah pelayanan publik selama pandemi Covid19 di Indonesia secara keseluruhan. Salah satunya adalah Neo dan Chen's Sebuah model pembangunan pemerintahan yang dinamis di Singapura. Pemerintah harus menerapkan tata kelola yang dinamis untuk merumuskan dan melaksanakan kebijakan adaptif melalui pengembangan kapabilitas dinamis (termasuk pemikiran ke depan, pemikiran ulang, dan pemikiran lintas kapabilitas) selama pandemi Covid-19 dalam hal memberikan pelayanan publik yang baik. 


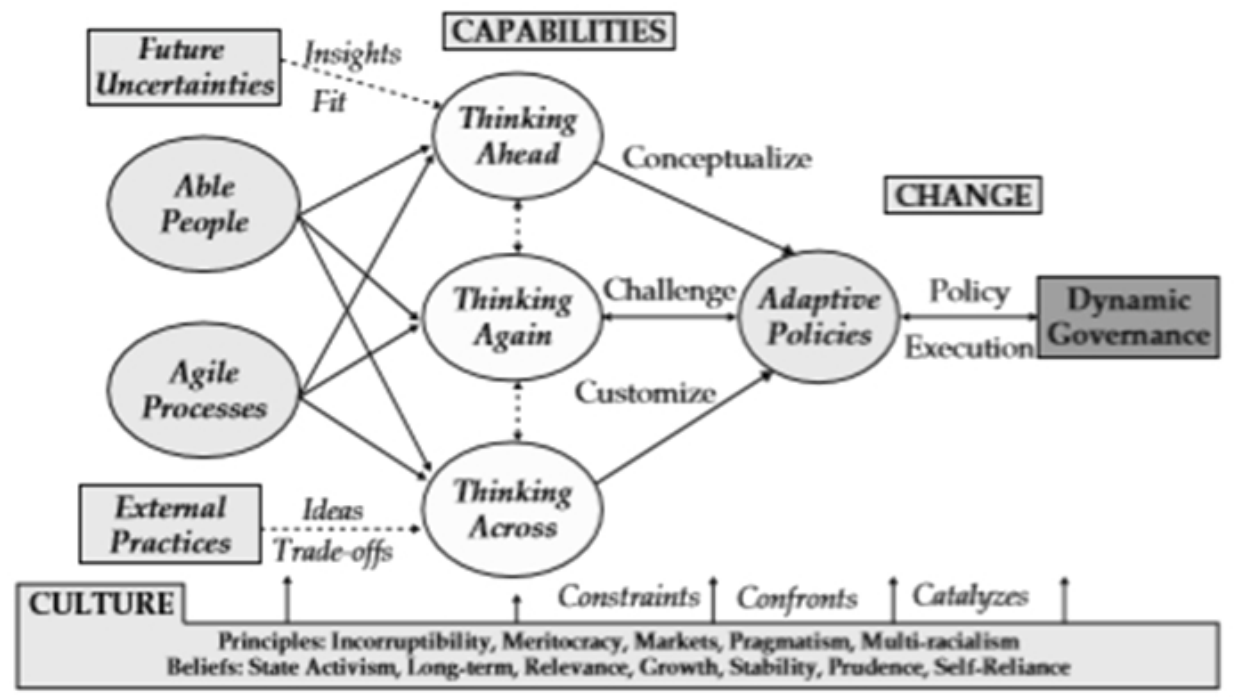

Gambar 1. Thinking Framework

Sumber: Neo, and Chen (2007: 12-46)

Kapabilitas Dynamic Governance dari Neo, Boon and Chen (2007) terdiri dari tiga indikator utama yaitu, Think Ahead atau berpikir ke depan, Think Again atau berpikir kembali, dan Think Across atau berpikir lintas batas yakni:

\section{Think Ahead (Berpikir ke depan)}

Kazim di dalam penelitian Tahir (2017) mengatakan bahwa Berpikir ke depan menunjukkan kemampuan berpikir tentang kondisi masa depan yang mungkin berdampak pada kondisi kelembagaan. Syafri (2012) la menjelaskan bahwa kemampuan berpikir ke depan dapat mengidentifikasi faktor lingkungan di masa depan melalui kebijakan yang adaptif, memungkinkan masyarakat untuk memanfaatkan peluang baru dan menghindari potensi ancaman yang dapat menghambat kemajuan sosial.

tujuan berpikir ke depan adalah untuk mendorong lembaga menilai risiko dari strategi dan kebijakan saat ini, memperbarui tujuan dan membuat konsep langkah-langkah kebijakan baru, dan mempersiapkan masa depan. Dalam kerangka konseptual, tata kelola dinamis terdiri dari budaya, kapabilitas, dan perubahan, yang bila dapat berinteraksi dan bekerja sama sebagai bagian dari sistem yang dinamis, ketiganya dapat dimaksimalkan.

Dalam hal ini pemerintah harus Menggali dan memprediksi tren dan perkembangan masa depan yang mungkin berdampak signifikan terhadap perumusan regulasi baru dalam hal pelayananan publik. Memahami bagaimana perkembangan ini akan mempengaruhi realisasi tujuan saat ini, dan menguji efektivitas strategi, kebijakan dan rencana yang ada. Opsi strategis apa yang dapat digunakan untuk mempersiapkan munculnya kasus baru dan memanfaatkan peluang baru dalam memaksimalkan pemberian layanan public secara general. Dan mempengaruhi pembuat keputusan dan para pemangku kepentingan utama untuk mempertimbangkan munculnya kasus lainnya seperti Covid-19 yang sangat 


\section{Journal Publicuho}

ISSN2621-1351 (online), ISSN 2685-0729 (print)

Volume 4 Number 1 (February-April), (2021)pp.158-170

Accredited SINTA SK.NOMOR 28/E/KPT/2019

Open Access at:http://ojs.uho.ac.id/index.php/PUBLICUHO/index

DOI: 10.35817/jpu.v4i1.16458

mempengaruhi kehidupan bermasyarakat termasuk kebutuhan masyarakat pada pelayanan public yang terus berjalan serta melibatkan asyarakat dalam percakapan strategis mengenai kemungkinan alternative lain untuk mendukung pemberian layanan public yang prima. Hal ini bertujuan untuk mengembalikan demokratisasi pelayanan public sehingga kembali pada poros kebutuhan masyarakat akan pelayanan dari pemerintah.

\section{Think Again ( Berpikir kembali)}

Syafri (2012) mengatakan bahwa berpikir kembali merupakan kemampuan menganalisa dan melakukan peninjauan ulang sebuah kebijakan, strategi, dan program. Menurut Aminullah (2015) Proses memikirkan kembali adalah meninjau dan menganalisis data kinerja aktual dan umpan balik dari peserta yang relevan.

Penelitian ini dilakukan untuk menganalisis system baru untuk mengatasi masalah berlandaskan strategi yang telah dirampung melalui sebuah kebijakan. Selanjutnya dengan melihat tingkat partisipasi masyarakat dan seperti apa upaya pemerintah Indonesia dalam melibatkan masyarakat untuk memberikan pelayanan publik yang transparan, akuntabel, dan bersifat partisipatif dimasa Covid-19.

Dalam hal ini pemerintah harus melakukan Tinjauan dan analisis data kinerja aktual, dan tanggapi pandemi COVID-19 untuk mendapatkan pemahaman publik. Meneliti penyebab umpan balik atau mengamati fakta, informasi dan perilaku. Meninjau strategi, kebijakan, dan rencana untuk mengidentifikasi fitur dan aktivitas yang berdampak baik, serta yang tidak berdampak. Mendesain ulang beberapa atau semua strategi dan prosedur untuk meningkatkan kinerja dan mencapai tujuan. Serta Menerapkan kebijakan dan sistem baru yang lebih relevan dengan masyarakat.

Maka dari itu pemerintah harus mencari dan mengadopsi praktik menarik yang dilaksanakan oleh negara lain dalam mengoptimalkan layanan public dimasa pandemic Covid19. Mengamati dan mempertimbangkan inovasi tersebut untuk di terapkan di Indonesia. Dan menilai faktor-faktor yang mungkin berlaku untuk situasi lokal, mempertimbangkan kondisi dan keadaan pandemi saat ini, dan kemungkinan penerimaan oleh masyarakat Indonesia.

\section{Think Across (Berpikir lintas batas)}

Kazim dalam Tahir (2017) menyatakan "Berpikir melintasi batas" menunjukkan wawasan dan keterbukaan pengalaman belajar ide dan konsep dari peserta lain. Kemampuan berpikir lintas batas merupakan kemampuan mengadopsi pemikiran, pendapat dan gagasan orang lain dari luar. Proses berpikir dapat menciptakan ide-ide baru dengan menggabungkan ide-ide dengan metode inovatif untuk mengatasi masalah yang muncul menurut Syafri (2012). 


\section{KETERKAITAN DYNAMIC CAPABILITIES DENGAN DEMOKRATISASI PELAYANAN PUBLIK DI MASA COVID-19}

Konsep kapabilitas dinamis merupakan aspek terpenting bagi pemerintah untuk memperoleh keunggulan kompetitif, yang dapat memprediksi ancaman dan menggunakan peluang untuk mendukung pencapaian tujuan yang diharapkan.

Kemampuan untuk berpikir ke depan, memikirkan kembali dan berpikir melintasi batas tidak hanya menjadi keterampilan independen, dan tidak boleh dioperasikan sebagai proses independen, tetapi kemampuan ini saling terkait, dan jika saling bergantung, mereka dapat digunakan sebagai Potensi sistem dapat diperluas dan dampak keseluruhan dapat diperkuat. Konsep ini melibatkan penentuan bagaimana memperjuangkan kesejahteraan masyarakat dan mencapai tujuan jangka panjang Negara dalam hal memberikan pelayhanan public secara maksimal. Oleh karena itu, dalam negara demokratis pendekatan yang dilakukan adalah dengan melibatkan seluruh pemangku kepentingan, yaitu pemerintah, swasta, dan masyarakat dalam merumuskan kebijakan dan menjalin hubungan antar pemangku kepentingan.

Terlepas dari pada itu, Konsep Dynamic Capabilities yang merupakan bagian dari dynamic governance ini merupakan bentuk nyata reformasi birokrasi. Maka dari itu demokratisasi pelayanan public di Indonesia dapat tercapai bila menerapkan ketiga indikator tersebut, yakni Thinking Ahead, Thinking Again, dan Thinking Across. Kapabilitas dinamis ini berhubungan dengan perkembangan paradigm new public management dan good governance dimana memunculkan tranformasi birokrasi termasuk pelayanan public. Dalam hal ini mengartikan bahwa adanya perkembangan pada sector public yang mendukung tercapainya tata kelola pemerintahan yang lebih baik dengan adanya kebijakan public yang adaptif terhadap perubahan lingkungan dan kebutuhan masyarakat yang harus dipenuhi. Korelasi yang timbul dalam sebuah kondep dynamic capabilities ini merupakan secara ekplisit berokus pada kemampuan sumber daya manusia (able people) dan proses bisnis organisasi (agile process) dalam membangun kebijakan public yang adaptif khususnya dalam hal pemberian layanan public.

Pelayanan publik di Indonesia telah sampai pada tahap reformasi pelayanan public, dimana hal ini membuktikan adanya perubahan keinginan dan kebutuhan masyarakat terhadap pemenuhan ha katas kewajiban pemerintah dalam memberikan pelayanan prima dan berkualitas. Tidak hanya coronavirus disease yang menjadi tantangan terbesar pemerintah saat ini, namun juga terdapat kompetisi regional dan nasional yang melibatkan teknologi sebagai terobosan terbaru dalam menciptakan pelayanan publik yang berkualitas. Hal ini berhubungan dengan munculnya demokratisasi pelayanan public sebagai goals baru pemerintah, dimana masyarakat memiliki kedudukan sebagai pelanggan (costumers) sekaligus warga dan stakeholders, hal ini seperti yang disampaikan oleh Denhardt dan Denhardt pada tahun 2003 yang membahas tentang perspektif New 


\section{Journal Publicuho}

ISSN2621-1351 (online), ISSN 2685-0729 (print)

Volume 4 Number 1 (February-April), (2021)pp.158-170

Accredited SINTA SK.NOMOR 28/E/KPT/2019

Open Access at:http://ojs.uho.ac.id/index.php/PUBLICUHO/index

DOI: 10.35817/jpu.v4i1.16458

Public Services. Tujuan dari demokratisasi pelayanan public ialah terwujudnya citizens first dalam pemberian layanan publik kepada masyarakat.

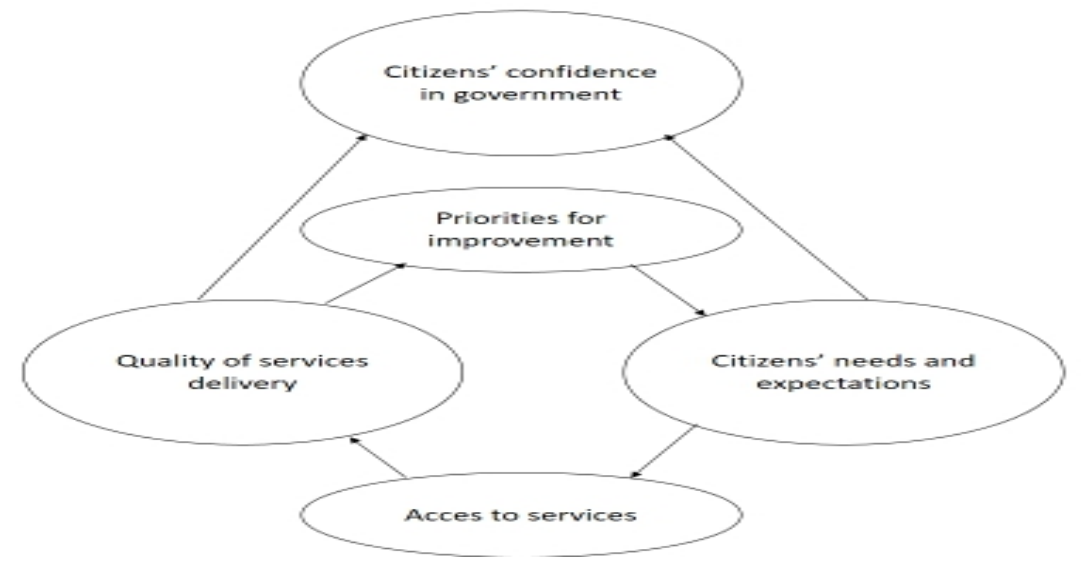

Gambar 2. The Citizens First Model

Sumber: Spears, dkk dalam Syafri dan silalahi (2015:209)

Berdasarkan gambar 2 di atas, dapat dijabarkan bahwa masyarakat dalam model The citizens first memiliki hak dalam hal penerimaan layanan publik, yakni adanya keyakinan masyarakat terhadap pemerintah dalam hal pemberian pelayanan publik yang dipengaruhi oleh kualitas pelayanan yang diberikan oleh pemerintah dan diterima oleh masyarakat dan kebutuhan serta ekspektasi masyarakat terhadap pelayanan tersebut. Dalam hal ini public trust menjadi faktor penentu keberhasilan atau ketercapaian pelayanan public yang diberikan oleh pemerintah. Implikasinya adalah masyarakat yang mendapatkan pelayanan dengan baik, sesuai dengan kebutuhan dan ekspektasi mereka, juga mendapatkan keuntungan seperti yang diharapkan maka akan lebih memiliki kepercayaan yang tinggi terhadap pelayanan yang diberikan pemerintah, begitu pula sebaliknya.

Maka dari itu konsep dynamic capabilities mampu mendukung keterwujudan masyarakat sebagai poros dari sebuah Negara dalam hal pelayanan public, yakni dalam bentuk demokratisasi yang menguntungkan masyarakat sebagai objek dari sebuah pelayanan. Mengingat bahwa demokrasi merupakan dari rakyat, oleh rakyat, dan untuk rakyat. Maka demokratisasi merupakan dua kali lipat standarisasi peningkatan demokrasi, yakni mempertimbangkan segala keputusan dan kebijakan berdasarkan kebutuhan dan ekspektasi masyarakat di Indonesia.

Mendemokratisasi pelayanan public merupakan bentuk dari transformasi birokrasi dalam konsep good governance. Dimana keberhasilan pemerintgah ditentukan oleh sejauh mana masyarakatnya memiliki pengetahuan terhadap Negara dan mampu mengikuti tgrend perkembangan zaman. Hal ini berhubungan dengan konsep dynamic capabilities neo and chen (2007) yang menggambarkan kondisi Negara singapura dalam sebuah konsep tata kelola pemerintahan yang dinamis. Yakni untuk mencapai peningkatan fleksibilitas organisasi sector public yang berhubungan langsung dengan kebutuhan 
masyarakat dalam menghadapi tantangan global (dalam kasus ini adalah pandemi Coronavirus Disease 2019) membutuhkan able people dan agile process sebagai penentu keberhasilan dari sebuah pelayanan publik dalam menghadapi faktor eksternal akibat wabah coronavirus disease 2019, wabah ini hadir secara tidak terduga mempengaruhi komponen dalam sebuah Negara, sehinga perlu adanya strukturisasi yang dalam penelitian ini berfokus pada aspek pelayanan public yang berkualitas. Sehingga demokratisasi pelayanan publik tersebut menjadi solusi alternative sekaligus memperbaharui pola budaya atau kebiasaan masyarakat dalam hal memenuhi kebutuhannya sebagai masyarakat dalam sebuah Negara yang berhak mendapatkan fasilitas baik dalam keadaan genting tidak terduga sekalipun seperti saat ini.

Adapun faktor-faktor yang berpengaruh dalam pengelolaan sumber daya aparatur (able people) yang didukung dengan keyakinan kuat adalah sebagai berikut: a. Pentingnya peran strategis dari fungsi kepemimpinan dan talent sangat dibutuhkan dalam untuk tata kelola pemerintahan yang baik, b. Sistem merit digunakan sebagai dasar dalam pelaksanaan seleksi, penempatan, promosi dan pemberhentian jabatan, dan c. Persyaratan yang mendasar bahwa pemimpin harus berasal dari orang-orang yang berpegang teguh pada kejujuran dan memiliki integritas yang kuat.

\section{KESIMPULAN}

Dynamic Capabilities yang memiliki komponen able people dan agile process merupakan urgensi pemerintah dalam memberikan pelayanan public yang optimal berlandaskan tiga indikator yaitu: berpikir kedepan untuk menghadapi tantangan di masa depan seperti wabah coronavirus disease 2019 (thinking ahead), berpikir kembali untuk mempertimbangkan kembali efektivitas dan efisiensi dalam pelaksanaan kebijakan dan program saat ini guna memberikan pelayanan yang bailk dimasa pandemic covid-19 (thinking again), serta berpikir intgas batas untuk memfasilitasi proses peningkatan pengetahuan dan edukasi melalui pemaparan berbagai ide baru, wawasan dan praktikpraktik terbaik yang berasal dari luar negeri untuk di adopsi di Indonesia (thinking across).

Dynamic capabilities memiliki komponen yang mendukung upaya demokratisasi pelayananan public guna meletakkan nilai demokrasi sebagai fondasi dalam pelayanan public. Demokratisasi mengutamakan kepentingan masyarakat sehingga meningkatkan kepercayaan masyarakat kepada kinerja dan upaya pemerintah dalam menghadapi wabah baru namun tetap efisien dalam hal pemberian layanan publik, yang didukung oleh mindset birokrasi yang transparan, partisipatoris, responsive, serta akuntabel dengan mengikutsertakan keadilan, nondiskriminatif, etis, integritas," dan professional. Dan melakukan transformasi paradigm masyarakat yang dulunya costumers, menjadi citizens confidence in government dengan menerapkan model the citizenz first. 


\section{Journal Publicuho}

ISSN2621-1351 (online), ISSN 2685-0729 (print)

Volume 4 Number 1 (February-April), (2021)pp.158-170

Accredited SINTA SK.NOMOR 28/E/KPT/2019

Open Access at:http://ojs.uho.ac.id/index.php/PUBLICUHO/index DOI: 10.35817/jpu.v4i1.16458

\section{DAFTAR PUSTAKA}

Afrizal., 2016., Metode Penelitian Kualitatif., Raja Grafindo Persada., Jakarta

Aminullah. 2015. Dynamic Governance (Kerangka Konseptual: Melembagakan Budaya, Kapabilitas, Dan Perubahan). Jurnal Kebangsaan, 9(1), 17-31.

Andara, R. 2019. Kapabilitas Dinamis Dalam Kepemimpinan Studi Atas Kepemimpinan Bupati Purwakarta Dedi Mulyadi. Jurnal Administrasi Publik, 1 (1), 1-18.

Andhika, L. R. 2017. Perbandingan Konsep Tata Kelola Pemerintah: Sound Governance Dynamic Governance, Dan Open Government ( Comparative Concept Of Governance: Sound Governance, Dynamic Governance, And Open Government ). Jurnal Ekonomi \& Kebijakan Publik, 8(2), 87-102.

Apriliani, F. T., Wibowo, H., Humaedi, S., \& Irfan, M. (2020). Model Keberfungsian Sosial Masyarakat Pada Kehidupan Normal Baru. Jurnal Kolaborasi Resolusi Konflik, 2(2), 133141.

Batinggi, A., \& Ahmad, B. (2013). Manajemen Pelayanan Publik. Yogyakarta: Andi Offset.

Denhardt, Robert B. and Joseph W. Grubbs. 1999. Public Administration: An Action Orientation, Orlando: Harcourt Brace College Publishers.

Darusman, F. 2020. Kapabilitas Dinamis Sektor Publik: Sebuah Tinjauan Literatur. Jurnal Ilmu Administrasi Negara, 16, 1-12.

Gulbrandsen, L. H. 2014. Dynamic Governance Interactions: Evolutionary Effects Of State Responses To Non-State Certification Programs. Regulation And Governance, 8(1), 74-92.

Haris, S. (Ed.). (2005). Desentralisasi dan otonomi daerah: desentralisasi, demokratisasi \& akuntabilitas pemerintahan daerah. Yayasan Obor Indonesia.

Hardy, F. R., Program, S., Masyarakat, K., \& Kesehatan, F. I. (2020). Herd Immunity Tantangan New Normal Era Pandemi Covid-19. 12, 2020.

Moenir, H. A. S, (2006). Manajemen Pelayanan Umum di Indonesia, Jakarta: Bumi Aksara.

Muhyiddin. (2020). Covid-19, New Normal dan Perencanaan Pembangunan di Indonesia Covid-19, New Normal dan Perencanaan Pembangunan di Indonesia. IV(2), 240-252.

Nugroho, H. (2012). Demokrasi dan Demokratisasi: Sebuah Kerangka Konseptual untuk Memahami Dinamika Sosial-Politik di Indonesia. Jurnal Pemikiran Sosiologi, 1 (1), 1-15.

Partini, P. (2012). Jurnal Pemikiran Sosiologi: Politik Adil Gender: Sebuah Paradoks. Jurnal Pemikiran Sosiologi Jurusan Sosiologi FISIPOL UGM, 1 (2), 39-51.

Rothan, H. A., \& Byrareddy, S. N. (2020). The epidemiology and pathogenesis of coronavirus disease ( COVID-19) outbreak. Journal of Autoimmunity, February, 102433. https://doi.org/10.1016/j.jaut.2020.102433

Sinambela, L. P. dkk. 2006. Reformasi Pelayanan Publik. 
Silalahi, U., \& Syafri, W. (2015). DESENTRALISASI DAN DEMOKRASI PELAYANAN PUBLIK: Menuju Pelayanan Pemerintah Daerah Lebih Transparan, Partisipatif, Responsif dan Akuntabel. IPDN PRESS.

Sedarmayanti, H., \& Dr, M. P. (2004). Good Governance (kepemerintahan yang baik). CV. Mandar Maju. Bandung.

Syafri, W. 2012. Studi Tentang Administrasi Publik. Jakarta: Erlangga

Tahir, M. Dan N. Z. 2017. Kapabilitas Dynamic Governance Dalam Optimalisasi Pengelolaan Lahan Terbuka Hijau Di Kota Makassar. Jurnal Ilmu Pemerintahan, 3(1), 1-13.

Zed, M. 2004. Metode Penelitian Kepustakaan. Jakarta: Yayasan Obor Indonesia. 